\title{
Dag Hammarskjöld, the United Nations and Africa
}

\section{Henning Melber ${ }^{1}$}

Once upon a time there was a Secretary-General of the United Nations (UN), who was elected into office during the Cold War era because the big powers believed he was just a humble servant to their interests. - They were wrong. Even-handedness, integrity, moral leadership, respect for otherness, loyalty to principles and ethical values, as enshrined in the UN Charter, were among the core values he represented. Dag Hammarskjöld held a firm belief in the autonomy of the office of the UN SecretaryGeneral and the Secretariat, which ought not to be degraded to a mere instrument and conference machinery serving the interests of the powerful states. Hammarskjöld was determined not to surrender the power of definition to individual member states.

During his term in office from April 1953 until his untimely death in September 1961 Dag Hammarskjöld (who succeeded the Norwegian Trygve Lie) was also heading the world organization during the period, when its transformation from an almost exclusively Western, post-World-War-II body towards a more global governance institution took place. This was the result due to a growing number of newly independent countries, not least from the African continent, which impacted on the international policy and geostrategic interests during the bipolar times of the so-called superpower rivalry.

Half a century and six Secretary-Generals later it is opportune to recall some of the virtues and convictions the Swedish diplomat represented like no other in this office. Against all odds, and at times bordering on stubbornness, he defended the autonomy of the office vis-à-vis the efforts by the big powers to execute their dominance also through the UN. This is in marked contrast to the role the world body has played since then in many international conflicts and subsequent interventions until today. Hence it is anything but an exercise in cultivating historical reminiscences, to revisit the role of the Secretary-General as defined and practised by Hammarskjöld during the initial years of Africa's decolonization.

Given the current shifts in global policies and interventions, in which the UN are even more involved than during Hammarskjöld's times, it is therefore worthwhile to recall what the cosmopolitan Swede represented during his time in office, not least for those in the global South and in particular the African colonies struggling for sovereignty and self-determination. More than by mere coincidence, the Chinese Permanent Representative to the UN, Li Baodong, during a debate in the UN Security Council on 26 August 2011 demanded that the peacekeeping operations of the organization 'should adhere to the Hammarskjöld principles'. ${ }^{2}$ In a similar vain, the Cyprus Foreign Minister Erato Kozakou-Marcoullis stressed in a speech on the occasion of a United Nations Day event on 20 October 2011 that 'especially small states like Cyprus would like to see the United Nations acting more solidly and with consistency to defend international law when it is being violated' and praised Dag Hammarskjöld 'as the dove of preventive diplomacy'. ${ }^{3}$ 


\section{Integrity, Colonialism and Solidarity}

On 31 October 1956, during the Suez crisis, Hammarskjöld stated before the Security Council in no uncertain terms that in his view 'the discretion and impartiality ... imposed on the Secretary-General ... may not degenerate into a policy of expediency'.4 He then already articulated what he reiterated in his introduction to the Annual Report of the UN for 1959-1960:

It is my firm conviction that any result bought at the price of a compromise with the principles and ideals of the Organization, either by yielding to force, by disregard of justice, by neglect of common interests or by contempt for human rights, is bought at too high a price. That is so because a compromise with its principles and purposes weakens the Organization in a way representing a definite loss for the future that cannot be balanced by any immediate advantage achieved. ${ }^{5}$

There is also anecdotal evidence of such steadfastness. In this case, the credible eyewitness reporting is the last personal assistant to Dag Hammarskjöld. As he recalled:

During an intermission in a debate in the Security Council, Dag was talking with the British Ambassador Sir Pierson Dixon in the corridor behind the podium. Sir Pierson suggested that the Secretary-General should make a statement in support of the British position. Dag refused. The ambassador insisted that, "After all, there is something called political sense." I stood there together with Dixon's assistant, Douglas Hurd (later to become Mrs. Thatcher's foreign secretary), when Dag, stressing each syllable, declared, "And there is something called integrity," turned around and closed the door behind him. ${ }^{6}$

As UN Secretary-General, Dag Hammarskjöld displayed some fascinating leadership qualities and set standards as an international civil servant. A trained economist, he was a far cry from the later versions of office bearers and often referred to as rather General than Secretary. But this did not mean that he had a closed mindset. When once asked over dinner by his friend John Steinbeck what would matter most during a world tour, Hammarskjöld reportedly answered: 'Sit on the ground and talk to people. That's the most important thing. ${ }^{7} \mathrm{He}$ had followed a similar approach (though not necessarily sitting on the ground while talking to the people) during a five-week trip through large parts of Africa. The journey lasted from 22 December 1959 to the end of January 1960. It took him to more than 20 countries on the continent, over which the 'winds of change' had begun to blow. Upon his return on 31 January, he declared at the airport in New York:

I would say that this experience over this long journey makes me less inclined than ever to generalize, less than ever willing to say this or that about Africa or this or that about the Africans, because just as there is very much in common, especially the aspirations, there is also an enormous diversity of problems, of attitudes, and of traditions. In such a way, the journey makes me both a little bit wiser and a lot more humble. ${ }^{8}$ 
In a subsequent press conference, Hammarskjöld elaborated on the approach he had outlined to his friend Steinbeck:

You can say that to stay in a country one night or two nights cannot give much of an experience. Well, first of all, it can. It can because, if you break through the walls and if you have the necessary background knowledge, even a talk of one hour can tell you more than volumes [...] It is not in particular what you can learn in this or that city or from this or that man that gives you valuable understanding of the situation. It is what he says and what you see in one city seen in the light of what you have heard others say and what you have seen in other cities. ${ }^{9}$

The trip attested to his general mindset and practice of seeking dialogue with others to explore the common ground of humanity. For Hammarskjöld, the UN was, as already stated in an address at Stanford University in June 1955, 'an expression of our will to find a synthesis between the nation and the world'. ${ }^{10}$ When upon his return from his visit to the African countries, a journalist inquired at the press conference whether the ideological trends in Africa 'stem from the inner realities facing African life today or whether they reflect the often repeated clichés of foreign ideology', Hammarskjöld's clarification left no doubt:

I do not think that the rights of man is a foreign ideology to any people and that, I think, is the key to the whole ideological structure in Africa at present. It may be that the most eloquent and the most revolutionary expressions of the rights of man are to be found in Western philosophers and Western thinking, but that certainly does not make the idea a Western idea imposed on anybody. ${ }^{11}$

The fundamental ethics that were his moral compass as a global leader guided his engagement not only with African realities. Not surprisingly, his role as the highest international civil servant representing the global governance institution established after World War II was based on values that were permeated by a notion of solidarity. On 26 January 1960, towards the end of his African journey, he declared at the second session of the Economic Commission of Africa in Tangier:

Partnership and solidarity are the foundations of the United Nations and it is in order to translate these principles into practical measures of economic cooperation that we are gathered today in this hall [...] The emergence of Africa on the world scene, more than any other single phenomenon, has forced us to reappraise and rethink the nature of relationships among peoples at different stages of development, and the conditions of a new synthesis making room for an accelerated growth and development of Africa. ${ }^{12}$

Hammarskjöld then reverted to a speech he had given a few months earlier at the University of Lund in Sweden, on 'Asia, Africa, and the West'. On that occasion, he had reminded his audience that 'nobody should forget that colonization reflected a basic approach which may have been well founded in certain limited respects, but which often mirrored false claims, particularly when it touched on spiritual development. Applied generally, it was untenable.'13 
Commenting on the Western perspectives of the early 20th century, Hammarskjöld found it striking 'how much they did not see and did not hear, and how even their most positive attempts at entering into a world of different thoughts and emotions were colored by an unthinking, self-assured superiority.' ${ }^{14}$ For Hammarskjöld, the 'richest satisfaction' lay in 'meeting different spiritual traditions and their representatives', provided one 'approaches them on an equal footing and with a common future goal in mind'. He was confident that this approach would ensure progress 'in the direction of a human community which, while retaining the special character of individuals and groups, has made use of what the various branches of the family of man have attained along different paths over thousands of years'.15

He clearly dismissed any claims to superiority over others based on any kind of naturalist concept of dominance rooted in supposed biological advancement and also questioned the legitimacy sought by dominant classes to justify their privileges:

The health and strength of a community depend on every citizen's feeling of solidarity with the other citizens, and on his willingness, in the name of this solidarity, to shoulder his part of the burdens and responsibilities of the community. The same is of course true of humanity as a whole. And just [as] it cannot be argued that within a community an economic upper class holds its favored position by virtue of greater ability, as a quality which is, as it were, vested in the group by nature, so it is, of course, impossible to maintain this in regard to nations in their mutual relationships. ${ }^{16}$

He therefore concluded:

We thus live in a world where, no more internationally than nationally, any distinct group can claim superiority in mental gifts and potentialities of development [...] Those democratic ideals which demand equal opportunities for all should be applied also to peoples and races [...] no nation or group of nations can base its future on a claim of supremacy. ${ }^{17}$

\section{Social and Economic Justice}

Hammarskjöld also had a strong sense of the need for economic justice. In his last address to ECOSOC, he linked the principles of national sovereignty to the belief that international solidarity and social consciousness must go hand in hand by:

[...] accepting as a basic postulate the existence of a world community for which all nations share a common responsibility [...] to reduce the disparities in levels of living between nations, a responsibility parallel to that accepted earlier for greater economic and social equality within nations. ${ }^{18}$

This corresponds with his earlier and continued emphasis on the need to address the economic imbalances inherent in the existing world order. As he stressed in an address as early as February 1956: 
the main trouble with the Economic and Social Council at present is that, in public opinion and in practice, the Council has not been given the place it should have in the hierarchy of the main organs of the United Nations. I guess that we are all agreed that economic and social problems should rank equal with political problems. In fact, sometimes I feel that they should, if anything, have priority. ${ }^{19}$

He testified further to his awareness of the needs for global economic justice only a few months later in his opening statement during a debate on the world economic situation in ECOSOC. In his remarks, he bemoaned

the absence of a framework of international policy that compels the underdeveloped countries each to seek its own salvation in its own way without reference to wider horizons. How often have we not heard the voices of those who bewail the fact that this underdeveloped country is moving along the slippery path to autarky, that that country is neglecting its exports, whether agricultural or mineral, or that yet a third country is manipulating its exchange rates in a manner contrary to the letter and spirit of the Bretton Woods agreements? And yet how many of those who belabor the underdeveloped countries in this fashion have given adequate thought to the structure of world economic relationships which has forced these countries into unorthodox patterns of behavior? ${ }^{20}$

The introduction to the 16th annual report of the UN became Hammarskjöld's last programmatic statement. Submitted a month before his untimely death, it underlined his firm belief in the equality of peoples and societies, as different from each other as these might be perceived to be:

In the Preamble to the Charter, Member nations have reaffirmed their faith 'in the equal rights of men and women and of nations large and small,' a principle which also has found many other expressions in the Charter. Thus, it restates the basic democratic principle of equal political rights, independently of the position of the individual or of the Member country in respect of its strength, as determined by territory, population or wealth. The words just quoted must, however, be considered as going further and imply an endorsement as well of a right to equal economic opportunities. ${ }^{21}$

Importantly, Hammarskjöld once again does not content himself with proclaiming noble postulates by making lofty reference to an abstract equality. As a trained economist ${ }^{22}$, he never lost sight of the socioeconomic dimensions of inequality. It is therefore no coincidence that he returns to stress the right to equal economic opportunities:

So as to avoid any misunderstanding, the Charter directly states that the basic democratic principles are applicable to nations 'large and small' and to individuals without distinction 'as to race, sex, language and religion,' qualifications that obviously could be extended to cover other criteria such as, for example, those of an ideological character which have been used or may be used as a basis for political or economic discrimination [...] The demand for equal economic opportunities has, 
likewise, been - and remains - of specific significance in relation to those very countries which have more recently entered the international arena as new states. This is natural in view of the fact that, mostly, they have been in an unfavourable economic position, which is reflected in a much lower per capita income, rate of capital supply, and degree of technical development, while their political independence and sovereignty require a fair measure of economic stability and economic possibilities in order to gain substance and full viability. ${ }^{23}$

In his last words to his staff, Hammarskjöld reiterated again one of his fundamental principles:

If the Secretariat is regarded as truly international, and its individual members as owing no allegiance to any national government, then the Secretariat may develop as an instrument for the preservation of peace and security of increasing significance and responsibilities. ${ }^{24}$

\section{The UN, Big Powers and the Congo}

Hammarskjöld's steadfastness when navigating through the manifold international interests vested in the Congo and seeking to influence his policies remain exemplary. Despite all efforts he resisted the pressure from the hegemonic states both in the East and the West to give in. When over the escalating conflicts of interest as played out between the powers seeking to secure their own agendas in the Congo the Soviet leader Nikita Khrushchev after the coup against the government of Lumumba accused Hammarskjöld of being a lackey of Western interests and demanded his resignation at the UN General Assembly in early October 1960, the Secretary-General responded with the following historical words:

It is not the Soviet Union or indeed any other Big Power who needs the United Nations for their protection, but all the others. In this sense, the Organisation is first of all their Organisation, and I deeply believe in the wisdom with which they will be able to use it and guide it. I shall remain in my post during the term of my Office as a servant of the Organisation in the interest of all those other nations, as long as they wish me to do so. ${ }^{25}$

He continued to stay on course also in the subsequent debates in the Security Council. Refuting the allegations that the UN acted in compliance with Western interests and held responsible for the brutal murder of Patrice Lumumba ${ }^{26}$, he stated on 13 February 1961 in another response in the Security Council to the continued demands for his resignation, which now were also increasingly made by the Belgian, French and British, who saw their vested economic interests at stake:

For seven or eight months, through efforts far beyond the imagination of those who founded this Organization, it has tried to counter tendencies to introduce the BigPower conflict into Africa and put the young African countries under the shadow of the cold war. It has done so with great risks and against heavy odds. It has done so at 
the cost of very great personal sacrifices for a great number of people. In the beginning the effort was successful, and I do not now hesitate to say that on more than one occasion the drift into a war with foreign-power intervention of the Korean or Spanish type was avoided only thanks to the work done by the Organization, basing itself on African solidarity. We effectively countered efforts from all sides to make the Congo a happy hunting ground for national interests. To be a roadblock to such efforts is to make yourself the target of attacks from all those who find their plans thwarted. (...) From both sides the main accusation was a lack of objectivity. The historian will undoubtedly find in this balance of accusations the very evidence of that objectivity we were accused of lacking, but also of the fact that very many Member nations have not yet accepted the limits put on their national ambitions by the very existence of the United Nations and by the membership of that Organisation. ${ }^{27}$

His even-handedness towards the big powers is documented by another incident, shared by Sture Linnér (1917-2010) with an audience attending his presentation at the annual Dag Hammarskjöld Lecture in October 2007 in Uppsala. Linnér was at the time of Hammarskjöld's death Under-Secretary-General in charge of the UN mission in the Congo. In July 1961 President JF Kennedy tried to intervene directly. Afraid of Antoine Gizenga coming into political power, then campaigning for election as Prime Minister and suspected of representing Soviet interests, Kennedy demanded that the UN should prevent Gizenga from seizing office. If not in compliance, the United States of America and other Western powers might withdraw their support to the UN. ${ }^{28}$ Reportedly, Hammarskjöld in a phone conversation with Linnér dismissed this unveiled threat with the following words:

I do not intend to give way to any pressure, be it from the East or the West; we shall sink or swim. Continue to follow the line you find to be in accordance with the UN Charter. ${ }^{29}$

Sture Linnér ended his Dag Hammarskjöld Lecture with the conclusion:

The Congo crisis could easily have provoked armed conflicts in other parts of Africa, even led to a world war. It was Dag Hammarskjöld and no one else who prevented that. And it is certain that for a suffering people he came to be seen as a model; he brought light into the heart of darkness. ${ }^{30}$

Dag Hammarskjöld, and with him 15 other persons (entourage and crew), died in the wreckage of the DC6 airplane, which crashed a few miles away from the airport approaching the Northern Rhodesian mining town of Ndola in the night from September 17 to 18,1961 . He was to meet close to the border to the Congo the leader of the Katangese secessionist movement, Moise Tshombe, in an effort to negotiate a peaceful solution to the civil war, after military efforts of the UN to bring an end to the Katangese secession had dismally failed. ${ }^{31}$ The circumstances of the plane crash remain - despite the findings of several official commissions of enquiry concluding that it was most probably a pilot's error - a matter of speculation. Too many questions have not 
been answered in a satisfactory manner, and it is not surprising that half a century later these questions resurface. ${ }^{32}$

\section{The Hammarskjöld Legacy}

The legacy Dag Hammarskjöld created during his lifetime remains over and above such efforts to investigate further the circumstances of his death. Suffice to conclude that it is an interesting aspect that suspicions are not completely unfounded or dismissed that some Western and settler-colonial interests, in alliance with the big mining companies in control over the mineral wealth, could have been at play when it came to the plane crash. This in itself points to the outstanding relevance attached to Hammarskjöld's anti-hegemonic convictions and role as second UN Secretary-General, as summarised in this essay. Not surprisingly, his principles are again recalled in times, when the world body has increasingly become an integral part of interventionist strategies, which seek to pursue the interests of the powerful.

Hammarskjöld's ethics, his concept of solidarity, his sense of fundamental universal values and human rights in combination with his respect for the multitude of identities within the human family, as well as his responsibility as the world's highest

international civil servant to assume global leadership, set standards that have to this day lost none of their value and relevance. The way he defined and executed his duties also with regard to the people of Africa can confidently be qualified as an act of international solidarity of a nature we are often missing today so painfully.

The hitherto most comprehensive documentation, providing new evidence suggesting that the plane crash was anything but a pilot's error, concluded that

Hammarskjöld's unswerving high principles and his determined search for peaceful solutions contributed to his death. A different Secretary-General, faced with the Katanga crisis in 1961, might have found an easier option than flying, exhausted, to a small town in central Africa to negotiate with an enemy of the United Nations. ${ }^{33}$

In one of the many review articles welcoming this investigative study, Michaela Wrong found herself

chafing at the detail, hungry instead to know more about the ideological convictions and strategic calculations that set Hammarskjöld, his Irish deputy Conor Cruise O'Brien and others at the UN on their high-risk course of geopolitical confrontation. Hammarskjöld once said 'It is better for the UN to lose the support of the US because it is faithful to law and principles, than to survive as an agent whose activities are geared to political purposes never avowed or laid down by the major organs of the UN.' I would have liked to know what UN officials in New York think of such sentiments today, whether they regard Hammarskjöld as dangerously naïve or superbly high-minded, and how UN policy since then has been influenced by the sneaking, terrible suspicion that a former boss paid for such defiance with his life. ${ }^{34}$ 
Henning Melber is Executive Director of The Dag Hammarskjöld Foundation in Uppsala/Sweden and Research Fellow at the Department of Political Sciences/University of Pretoria. E-mail: Henning.Melber@dhf.uu.se.

\section{Endnotes}

1 This is the revised version of a paper presented at the Conference 'Dag Hammarskjöld, the United Nations, and the End of Empire' organized by the Institute of Commonwealth Studies, the School of Advanced Studies/University of London, the Dag Hammarskjöld Foundation and the United Nations Association/Westminster Branch at the University of London, 2 September 2011. I am grateful for the suggestions by an anonymous reviewer, which helped to improve the text.

2 “China calls for necessary improvement of peacekeeping theory, practice”, People's Daily Online, 27 August 2011, http://english.peopledaily.com.cn/90883/7581592.html.

3 "FM: UN must prove its effectiveness", Famagusta Gazette, 21 October 2011, http://famagustagazette.com/fm-un-must-prove-its-effectiveness-p13258-69.htm.

${ }^{4}$ Quoted from Kaj Falkman (ed.), To Speak for the World. Speeches and Statements by Dag Hammarskjöld. Stockholm: Atlantis 2005, pp. $120 \mathrm{f}$.

5 Ibid., p. 71.

${ }^{6}$ Wilhelm Wachtmeister, "Leader - Statesman - Friend", in Mary Lynn Hanley/Henning Melber (eds), Dag Hammarskjöld Remembered. A Collection of Personal Memories. Uppsala: The Dag Hammarskjöld Foundation 2011, p. 82.

7 Per Lind and Bengt Thelin, 'Nature and Culture: Two Necessities of Life', in Sten Ask and Anna MarkJungkvist (eds), The Adventure of Peace: Dag Hammarskjöld and the Future of the UN, New York and London: Palgrave Macmillan 2005, p. 99.

8 'Airport Statement on Return from African Trip', New York, 31 January 1960 (UN Press Release SG/895, 31 January 1960), in Andrew W. Cordier and Wilder Foote (eds), Public Papers of the Secretaries-General of the United Nations. Volume V: Dag Hammarskjöld 1960-1961, New York and London: Columbia University Press 1975, p. 522.

9 'From Transcript of Press Conference.' New York, 4 February 1960 (UN Note to Correspondents No. 2108, 4 February 1960), in ibid., p. 525.

10 "The World and the Nation." Commencement Address at Stanford University, Palo Alto, California, June 19, 1955 (UN Press Release SG/426, June 18, 1955). In: Andrew W. Cordier/Wilder Foote (eds), Public Papers of the Secretaries-General of the United Nations. Volume II: Dag Hammarskjöld 1953-1956. New York und London: Columbia University Press 1975,. 512.

11 'From Transcript of Press Conference', op. cit., pp. 533-4.

12 'Statement at the Second Session of the Economic Commission for Africa', Tangier, Morocco, 26 January 1960 (UN Press Release SG/890, 25 January 1960), in Andrew W. Cordier and Wilder Foote (eds), Public Papers ... Volume V, op. cit., p. 517.

13 'Asia, Africa, and the West', Address Before the Academic Association of the University of Lund, Lund, Sweden, 4 May 1959 (UN Press Release SG/813, 4 May 1959), in Andrew W. Cordier and Wilder Foote (eds), Public Papers ... Volume IV: Dag Hammarskjöld 1958-1960, New York and London: Columbia University Press 1974, p. 381.

${ }^{14}$ Ibid., p. 382 (original emphasis).

15 Ibid.

16 Ibid., p. 383.

17 Ibid., p. 384.

18 Quoted in Sakiko Fukuda-Parr, 'Poverty and Inequality - Challenges in the Era of Globalisation', in Sten Ask and Anna Mark-Jungkvist (eds), op. cit., p. 222.

19 'The UN - Its Ideologies and Activities', in Andrew W. Cordier and Wilder Foote (eds), Public Papers ... Volume II, op. cit., p. 668.

20 '1. Statement in the Economic and Social Council Introducing Debate on the World Economic Situation', Geneva, 16 July 1956 (UN Press Release SG/493, 16 July 1956), in Andrew W. Cordier and Wilder Foote (eds), Public Papers ... Volume III, Dag Hammarskjöld 1956-1957, New York and London: Columbia University Press 1973 , pp. $190 \mathrm{f}$. 
21 'Introduction to the Sixteenth Annual Report', New York, 17 August 1961, in Andrew W. Cordier and Wilder Foote (eds), Public Papers ... Volume V, op. cit., p. 544.

${ }^{22}$ Hammarskjöld defended his PhD with no less a person than Gunnar Myrdal as disputant, who disagreed with Hammarskjöld on the argument in his thesis but advocated the award of the highest mark for the undisputable quality of his analyses.

${ }^{23}$ Ibid., p. 545 (original italics).

24 'Last Words to the Staff - from Remarks on Staff Day', New York, 8 September 1961, in ibid., p. 564.

${ }^{25}$ Quoted from Falkman, op. cit., p. 86.

${ }^{26}$ See for this critical position most prominently Ludo de Witte, The Assassination of Lumumba. London: Verso 2001.

${ }^{27}$ Second Statement After Soviet Demand for His Dismissal. New York, February 13, 1961. Security Council Official Records, Sixteenth Year, 933rd meeting. In: Andrew W. Cordier and Wilder Foote (eds), Public Papers ... Volume V, op. cit., pp. 349f.

${ }^{28}$ See for this period and the unusual blunt intervention the comprehensive documentation in Madeleine G. Kalb, The Congo Cables: The Cold War in Africa - From Eisenhower to Kennedy. New York: Macmillan 1982, pp. 274-276.

${ }^{29}$ Sture Linnér, Dag Hammarskjöld and the Congo crisis, 1960-61. In: Sture Linnér and Sverker Åström, UN Secretary-General Hammarskjöld. Reflections and personal experiences. The 2007 Dag Hammarskjöld Lecture. Uppsala: Dag Hammarskjöld Foundation and Uppsala University 2008, p. 26.

30 Ibid., p. 29.

${ }^{31}$ See for a critical analysis, which shifts the blame from Hammarskjöld to some of his closest assistants some of the chapters in Robert A. Hill/Edmond J. Keller (eds), Trustee for the Human Community. Ralph J. Bunche, the United Nations, and the Decolonization of Africa. Athens, Ohio: Ohio University Press 2010. 32 For a concise overview on the different speculations and explanations see Manuel Fröhlich, "'The Unknown Assignation': Dag Hammarskjöld in the Papers of George Ivan Smith", in Beyond Diplomacy. Perspectives on Dag Hammarskjöld. Uppsala: Dag Hammarskjöld Foundation 2008 (Critical Currents; no. 2), pp. 27-33. See as the latest, most coherent and comprehensive effort to explore the dubious aspects of the plane crash further Susan Williams, Who Killed Hammarskjöld? The UN, the Cold War and White Supremacy in Africa. London: Hurst 2011.

${ }^{33}$ Ibid., p. 240.

${ }^{34}$ Michaela Wrong, "Who Killed Hammarskjöld? By Susan Williams". The Spectator, 29 October 2011, http://www.spectator.co.uk/books/7342003/who-killed-hammarskjld-by-susan-williams.thtml. 